the Total Environment

Elsevier Editorial system(tm) for science of Manuscript Draft

Manuscript Number: STOTEN-D-17-01181R1

Title: Modelling of Escherichia coli concentrations in bathing water at microtidal coasts

Article Type: Research Paper

Keywords: numerical modelling; E. coli; beaches; water quality

Corresponding Author: Mr. Luis Aragones Pomares, Assistant Professor

Corresponding Author's Institution: University of Alicante

First Author: Antonio Palazón

Order of Authors: Antonio Palazón; Isabel López; Luis Aragones

Pomares, Yolanda Villacampa; Francisco J Navarro-González

Abstract: Monitoring of the quality of bathing water in line with the European Commission bathing water directive (Directive 2006/7/EC) is a significant economic expense for those countries with great lengths of coastline. In this study a numerical model based on finite elements is generated whose objective is partially substituting the microbiological analysis of the quality of coastal bathing waters. According to a study of the concentration of Escherichia coli in 299 Spanish Mediterranean beaches, it was established that the most important variables that influence the concentration are: monthly sunshine hours, mean monthly precipitation, number of goat cattle heads, population density, presence of Posidonia oceanica, UV, urbanization level, type of sediment, wastewater treatment ratio, salinity, distance to the nearest discharge, and wave height perpendicular to the coast. Using these variables, a model with an absolute error of $10.6 \pm 1.5 \mathrm{CFU} / 100 \mathrm{ml}$ is achieved. With this model, if there are no significant changes in the beach environment and the variables remain more or less stable, the concentration of $E$. coli in bathing water can be determined, performing only specific microbiological analyses to verify the water quality. 


\section{Modelling of Escherichia coli concentrations in bathing water at microtidal coasts}

2

3

4

5

6

A. Palazón ${ }^{(a)}$, I. López ${ }^{(b)}$, L. Aragonés ${ }^{\left(b^{*}\right)}$, Y. Villacampa ${ }^{(c)}$, F.J. Navarro-González ${ }^{(c)}$

(a) Dept. of Civil Engineering, Catholic University of Murcia, Campus de los Jerónimos, № 135 Guadalupe 30107 Murcia, Spain.

(b) Dept. of Civil Engineering, University of Alicante, Carretera San Vicent del Raspeig s/n, 03690 Alicante, Spain.

(c) Dept. of Applied Mathematics, University of Alicante, Carretera San Vicent del Raspeig s/n, 03690 Alicante, Spain.

${ }^{(*)}$ Corresponding author. Luis Aragonés. E-mail: laragones@ua.es

\section{ABSTRACT}

Monitoring of the quality of bathing water in line with the European Commission bathing water directive (Directive 2006/7/EC) is a significant economic expense for those countries with great lengths of coastline. In this study a numerical model based on finite elements is generated whose objective is partially substituting the microbiological analysis of the quality of coastal bathing waters. According to a study of the concentration of Escherichia coli in 299 Spanish Mediterranean beaches, it was established that the most important variables that influence the concentration are: monthly sunshine hours, mean monthly precipitation, number of goat cattle heads, population density, presence of Posidonia oceanica, UV, urbanization level, type of sediment, wastewater treatment ratio, salinity, distance to the nearest discharge, and wave height perpendicular to the coast. Using these variables, a model with an absolute error of $10.6 \pm 1.5 \mathrm{CFU} / 100 \mathrm{ml}$ is achieved. With this model, if there are no significant changes in the beach environment and the variables remain more or less stable, the concentration of $E$. coli in bathing water can be determined, performing only specific microbiological analyses to verify the water quality.

Keywords: numerical modelling; E. coli; beaches; water quality

\section{Introduction}

In the last fifty years enjoying leisure time on the coast throughout the year has increased in popularity. This requires minimum standards of quality in the coastal areas and its bathing waters to ensure the health of the users (Sardá et al., 2005). For this reason, the European health administration has been monitoring the quality of bathing water for more than 20 years. Bathing waters are the surface waters where a significant number of people are expected to bathe or there is an activity directly related to water sports.

Monitoring the quality of coastal waters is carried out mainly in accordance with the European Directive on bathing waters (Directive 2006/7 / EC), measuring the concentration of Escherichia coli and intestinal Enterococci. These bacteria, present in the microbiota of humans and warm-blooded animals (Callahan et al., 1995; Gantzer et al., 1998), are used as an index of faecal contamination because they can cause gastrointestinal and respiratory tract infections, as well as ears, eyes, nasal 
cavity or skin illness (W.H.O., 2003). Depending on the risk of infection, Directive 2006/7/EC classifies coastal waters as: excellent, good, sufficient and insufficient. The established limit values may, in rare circumstances, be adapted by the local authorities to each space, depending on the social, cultural, environmental and economic conditions.

The variation in the concentration of these bacteria depends on many factors. On the one hand, physical characteristics such as beach environment, sediment type, radiation, or salinity are important variables. For example, urban beaches (with greater urban development and greater number of users) present lower quality than natural or semi-urban beaches (Ariza et al., 2010; May et al., 1999; McLellan, 2004; Winter and Duthie, 1998). The type of sediment (gravel or sand) is also important, since $E$. coli can reproduce in sand, because it is a humid environment, rich in organic matter (Alm et al., 2006; Yamahara et al., 2007). Furthermore, the type of sediment is directly related to the disinfection capacity of ultraviolet light (UV), which inactivates the microorganisms in the water (Salcedo et al., 2002), the greater the number of suspended solids in the water the lower disinfection capacity (Abdelzaher et al., 2010; Haugland et al., 2005; Salcedo et al., 2002). This is one of the reasons why sandy beaches have higher concentrations of bacteria than gravel beaches (Aragonés et al., 2016a).

On the other hand, beach users, pets (dogs) and birds, especially seagulls, are sources of this type of bacteria in the sand and therefore in the water (Abdelzaher et al., 2010; Haugland et al., 2005; Whitman et al., 2004). Likewise, livestock and agricultural developments near the beaches have adverse effects on the microbial quality of bathing water, with the negative effects mainly due to rainfall (Ackerman and Weisberg, 2003). Several authors have also related the concentration of $E$. coli to the presence of some species of marine vegetation. For example, Cladophora favours the survival of E. coli (Beckinghausen et al., 2014; Englebert et al., 2008; Vanden Heuvel et al., 2010), while other algae like Ulva rigida, Codium bursa, Cystoseira barbata, Ceramium diaphanum Acanthophora sp., Bryothamnion triquetrum, Gracilaria sp., Gelidium sp., Caulerpa mexicana, Caulerpa sp., Halimeda incrassata, Ulva sp., Codium decorticatum, Sargassum sp. or Posidonia oceanica have an antibacterial activity against E. coli (Frikha et al., 2011; Hammami et al., 2013; Luzi et al., 2016; Ríos et al., 2009).

Historically, monitoring programs have led to geospatial analysis models (Grayson et al., 2008; Kelsey et al., 2004; Knothe, 2012), tracking microbial source (McQuaig et al., 2012), and evaluating microbial networks (Brooks et al., 2008; Faust and Raes, 2012) to more accurately predict human health risks after exposure to contamination. However, there are still difficulties in establishing predictive models, since microbial contamination can come from multiple point and non-point sources (Stewart et al., 2008), but having a large database can facilitate modelling (Mill et al., 2006). For example, Partyka et al. (2017), through 1740 samples, established data collection sites, and generated a model to predict changes in concentration in areas subject to large seasonal variations.

The objective of this study is to obtain a model that allows us to determine the concentration of $E$. coli in coastal bathing waters, in order to reduce the number of microbiological analyses. First, the correlations between $E$. coli concentration in 299 beaches and 33 variables related to climate, maritime climate, physical characteristics, environment, fauna and flora were studied. Next, different mathematical models were generated, and the optimum model was validated using data from later years. 


\section{STUDY AREA}

The study area comprises 299 beaches along $983 \mathrm{~km}$ of the Spanish Mediterranean coast (Fig. 1), specifically the beaches located in the provinces of Valencia ( 47 beaches), Alicante ( 94 beaches), Murcia ( 37 beaches), Almeria ( 65 beaches) and Granada ( 27 beaches). It is a microtidal area where astronomical tides range from between $20 \mathrm{~cm}$ and $40 \mathrm{~cm}$, and when affected by meteorological factors, the tide surges can be up to $75 \mathrm{~cm}$ (EcoMAG, 2009).

The zone to the North of the Cape of the Nao is bordered by marshes intensely transformed by the agricultural activity (Fig. 1a), while to the south to the Amadorio River the coast is characterized by a landscape of small coves and cliffs (Fig. 1b). Towards south there are dune ridges, beaches and lagoons such as Torrevieja or Guardamar (Fig. 1c). On the coast of Murcia, there is an important dune strip that forms the Mar Menor, which presents a higher temperature and salinity than the Mediterranean Sea. From Cape Palos to the border of the province of Granada, the coastal plains are very narrow and the coast is formed by cliffs and small beaches, except for the valleys of some rivers. The rivers throughout the study area are generally short and the flows have an important seasonal character.

An important feature of the study area is the extensive presence of Posidonia oceanica meadows on the seabed (Fig. 1d). Posidonia oceanica is a marine plant endemic to the Mediterranean and forms large meadows on sandy bottoms near the coast. To develop, Posidonia meadows need good quality, uncontaminated, transparent and well oxygenated waters, that is, their presence is representative of the good quality of the waters in which are located.

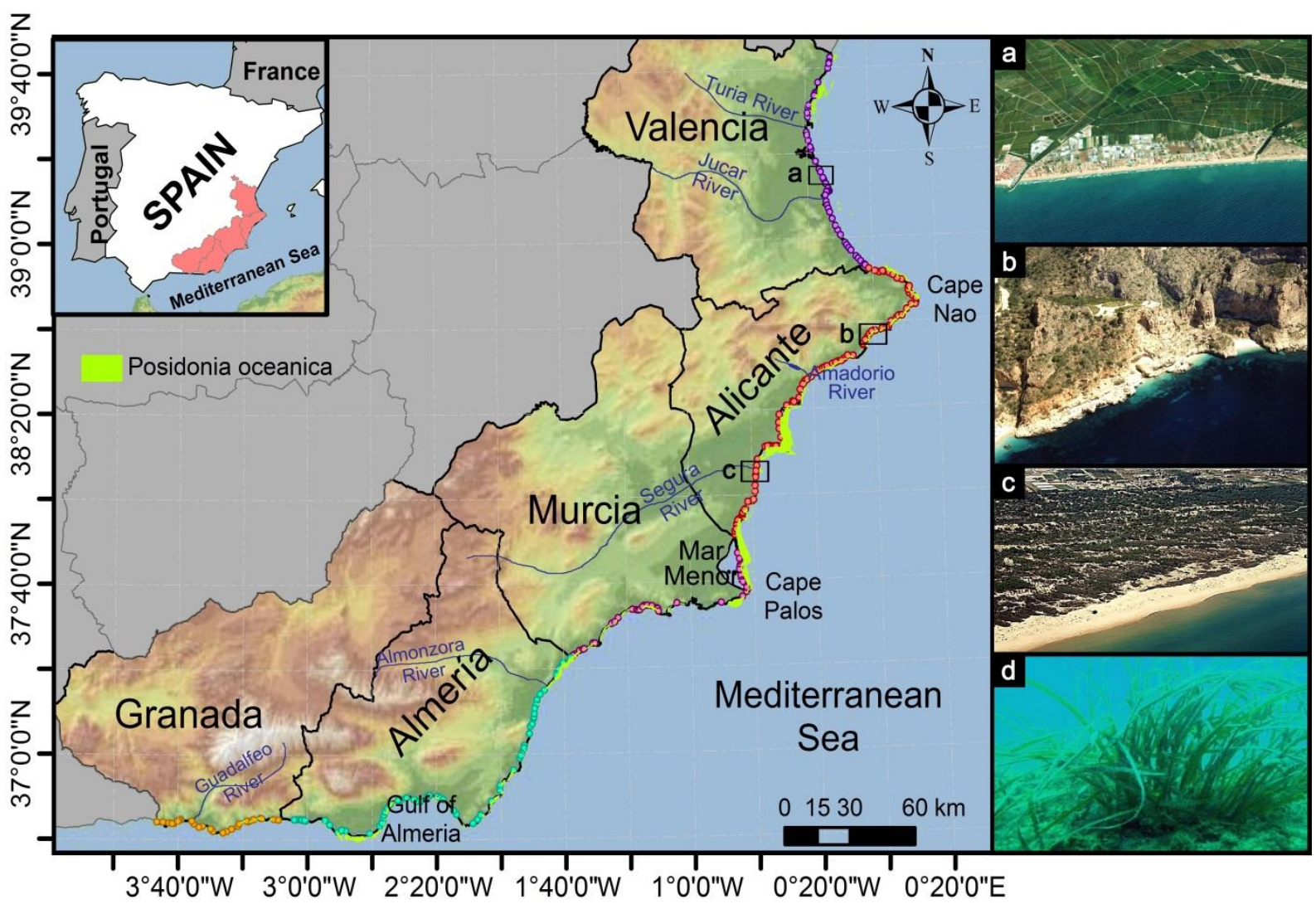

Fig. 1. Location of the study area, the Posidonia oceanica meadows, as well as the 299 beaches studied. a) Agricultural area. b) Cliffs and coves. c) Dune strips. d) Posidonia oceanica. 
The work was carried out in four phases: data collection and organization, analysis of variables, generation of models, and finally, validation.

\subsection{Data collection}

In this study, 33 variables have been analysed and can be grouped according to their relationship with: climatology (water temperature, hours of sun, ultraviolet radiation, rainfall or wind); maritime climate (wave height and salinity); physical characteristics (sediment, environment, density and population, morphology, orientation); livestock (goats, sheep or cow); sources of discharges and purification; and the existence of Posidonia oceanica (existence, depth, width of the meadow, etc.). Table 1 shows a summary of the studied variables and their origin.

Table 1. Summary of the studied variables and their origin.

\begin{tabular}{|c|c|c|}
\hline Parameters & Variables & Origin \\
\hline Faecal bacteria & E. coli (CFU/100 ml) & $\begin{array}{c}\text { Treatment according to Directive } \\
\text { 2006/7/EC of data from the Nayade (2016) } \\
\text { database }\end{array}$ \\
\hline \multirow[b]{2}{*}{$\begin{array}{c}\text { Physical } \\
\text { characteristics }\end{array}$} & $\begin{array}{l}\text { Sediment (sand, sand with scattered rocks, sand and } \\
\text { gravel, gravel and with scattered rocks, and rocks) } \\
\text { Level of urbanization (urban, semi-urban, natural) }\end{array}$ & $\begin{array}{l}\text { Visual corroboration of data from the } \\
\text { MAGRAMA (2016b) database }\end{array}$ \\
\hline & $\begin{array}{l}\text { Orientation (North, North-Northeast, Northeast, } \\
\text { East-Northeast, East, East-South, etc.) } \\
\text { Morphology (open, supported, Bi-supported, } \\
\text { enclosed) }\end{array}$ & $\begin{array}{c}\text { Measurement through a GIS system of } \\
\text { data from Ecolevante (2006) and EcoMAG } \\
\text { (2009) }\end{array}$ \\
\hline Population & $\begin{array}{l}\text { Population per town } \\
\text { Population density (pop/ } / \mathrm{km}^{2} \text { ) }\end{array}$ & INE (2016)database \\
\hline Climatology & $\begin{array}{l}\text { Ultraviolet (UV) rays } \\
\text { Average monthly precipitation (mm/month) } \\
\text { Average hours of sunshine per month ( } / \text { month) }\end{array}$ & AEMET (2016) database \\
\hline \multirow[b]{2}{*}{ Maritime climate } & $\begin{array}{l}\text { Average salinity (PSU) } \\
\text { Average water temperature }\left({ }^{\circ} \mathrm{C}\right)\end{array}$ & Puertos del Estado (2016) database \\
\hline & $\begin{array}{l}\text { Wind velocity perpendicular to the coast }(\mathrm{m} / \mathrm{s}) \\
\text { Wave height perpendicular to the coast }(\mathrm{m}) \\
\text { Period associated with wave height }(\mathrm{s})\end{array}$ & $\begin{array}{c}\text { Treatment using AMEVA v.1.4.3 software } \\
\text { of data from Puertos del Estado (2016) } \\
\text { database }\end{array}$ \\
\hline Livestock & $\begin{array}{l}\text { Heads of cattle (total number of cattle head/town) } \\
\text { Goat cattle (number of cattle head/town) } \\
\text { Sheep cattle (number of cattle head/town) } \\
\text { Pig cattle (number of cattle head/town) } \\
\text { Other cattle (number of cattle head/town) } \\
\end{array}$ & MAGRAMA (2016a) \\
\hline \multirow[b]{2}{*}{$\begin{array}{l}\text { Purification rate } \\
\text { and } \\
\text { source discharges }\end{array}$} & Purification rate (percentage of purified wastewater) & MAGRAMA (2016c) database \\
\hline & $\begin{array}{l}\text { Ravines or rivers } \\
\text { Distance to ravines or river }(\mathrm{m}) \\
\text { Residual discharges } \\
\text { Distance to residual discharges }(\mathrm{m}) \\
\text { All discharges (rivers, gullies and waste) } \\
\text { Distance to any type of discharge }(\mathrm{m}) \\
\end{array}$ & $\begin{array}{l}\text { Measurement through a GIS system of } \\
\text { data from Ecolevante (2006) and EcoMAG } \\
\text { (2009) }\end{array}$ \\
\hline \multirow[t]{2}{*}{$\begin{array}{l}\text { Posidonia } \\
\text { oceanica }\end{array}$} & $\begin{array}{l}\text { Presence of Posidonia oceanica } \\
\text { Meadow final depth }(\mathrm{m}) \\
\text { Meadow medium depth }(\mathrm{m}) \\
\text { Meadow initial depth }(\mathrm{m}) \\
\text { Meadow width }(\mathrm{m}) \\
\end{array}$ & $\begin{array}{c}\text { Measurement through a GIS system of } \\
\text { data from Ecolevante (2006) and EcoMAG } \\
\text { (2009) }\end{array}$ \\
\hline & $\begin{array}{l}\text { Stem height }(\mathrm{cm}) \\
\text { Plant density }\left(\mathrm{stems} / \mathrm{m}^{2}\right)\end{array}$ & $\begin{array}{c}\text { Ecolevante (2006) and EcoMAG (2009) } \\
\text { databases }\end{array}$ \\
\hline
\end{tabular}


Escherichia coli concentrations in each of the beaches were obtained from the database published by Nayade (2016) for the surveys conducted between 2012 and 2016. The data for 2012-2015 were used for the model adjustment, while the data from 2015-2016 were used for validation. These data were processed according to Directive 2006/7/EC to obtain P95 values of E. coli in each of the studied beaches. For more information on sampling, cadence of data collection, detection methods, etc., see http://nayade.msc.es/Splayas/home.html.

All data on climatology, population and maritime climate refer to the average of the period studied during the bathing season (May-September). The wave height $\mathrm{H}_{\mathrm{s}, 12}$ (wave height exceeded 12 hours per year or with a probability of being exceeded of $0.137 \%$ ), its associated mean period $(T)$ and the median wind speed were calculated using the software AMEVA v1.4.3 (IHCantabria, 2013).

Regarding the physical characteristics, beach morphology was divided into four groups (open, supported, bi-supported and enclosed) as were proposed by López et al. (2015). The beaches were classified into 16 groups according to their orientation as follows: A perpendicular line was drawn from the coastline of each beach, thereby enabling us to read its orientation as given by the wind rose. A visual inspection of the sediment resulted in a classification into five groups: sand, sand with scattered rocks, sand and gravel, gravel with scattered rocks, and rocks. The level of urbanization was obtained from the MAGRAMA (2016b) classification, which follows the guidelines established by Ariza et al. (2010), distinguishing between urban, semi-urban and natural beaches.

Several types of discharges to the beaches can be found such as: rivers, ravines and residual discharges. Residual discharges, in turn, can be grouped in five types, according to their origin and end point: 1 ) outfall (discharge directly in the beach or nearby); 2 ) submarine outfall (discharges more than $500 \mathrm{~m}$ from the shoreline); 3) agricultural; 4) diffuse: generic, industrial and storm water; and 5) WWTP (Wastewater Treatment Plant). A GIS (Geographic Information System) system was used to measure the distance between each point of discharge and the midpoint of the beach in the direction of the main wave flow in each zone. The littoral discharge closest to the shoreline was selected, provided that the distance from the shoreline was less than $2 \mathrm{~km}$. If the distance to the discharge point was greater than $2 \mathrm{~km}$, it was considered that no discharge existed on the beach.

The characteristics of the Posidonia oceanica meadows (width and depth) were obtained by measuring the GIS data from Ecolevante (2006) and EcoMAG (2009). The remaining data (plant density and stem height) were obtained from the files of each of the Posidonia meadows found in the databases of the previous studies (Ecolevante, 2006; EcoMAG, 2009). For more information about the variables used see supplementary material 1.

\subsection{Mathematical modelling}

For the study and modelling of $E$. coli bacteria in the coastal waters, first the principal component analysis (PCA) and bivariate correlations were analysed. The bivariate Pearson Correlation produces a sample correlation coefficient $(r)$ which measures the strength and direction of linear relationships between pairs of continuous variables. By extension, the Pearson Correlation evaluates whether there is statistical evidence for a linear relationship among the same pairs of variables in the population. This methodology is advantageous because it is less sensitive to atypical values and biased distributions, and works well even when there is strong interaction between input variables (Liao et al., 2016). 
After the study of correlations, the selection of variables to be included in the different models was a function of:

- Degree of correlation

- The ease of obtaining the data of the variable

- The relative importance of these variables according to other research

For the generation of mathematical models, several methodologies were used. First, linear models (S-Plus2000, 1999) and (SPSS12.0., 2003), were determined. From the study of linear models, the results indicate that the existing relationship is not linear since the estimated regression coefficient is 0.23 . For this reason, numerical models were used. Different numerical models (using data from the period 2012-2015) were generated using the methodologies based on the finite element method (Navarro-González and Villacampa, 2013; Navarro-González and Villacampa, 2012) and the formulation of the Galerkin method (Navarro-González and Villacampa, 2016).

The methodologies of Navarro-González and Villacampa $(2012,2013)$ are numerical methodologies that allow the generation of models to represent the relationship between independent variables and a dependent variable(s), from the interpolation defined in n-dimensional finite element model, which is generated from the experimental data. The interpolation function implies the use of some initial conditions, which in the defined methodology implies the coincidence between the values of the function in a finite number of points. As normally occurs when applying the finite element method, the model function is obtained in a finite set of points called nodes (Zienkiewicz et al., 1977). In the applied methodologies, an optimization problem based on the determination of the minimum of an error function, generically defined in a finite element model, was solved. To improve the speed of resolution when the number of variables used is high (as in the case of some of the models generated in this paper), the methodology developed by Navarro-González and Villacampa (2016) was used.

In both methodologies, the experimental data are normalized to the $\mathrm{n}$-dimensional hyper-cube, given by $\Omega=[0,1]^{n}$. Each interval $[0,1]$ is divided into $c$ subintervals ( $c$ is called the complexity of the model). A set of $c^{n}$ elements and $(c+1)^{n}$ nodes is generated, where the relationship between the independent variables and the dependent variable(s) is calculated. For example, if we consider a 3-dimensional geometric model with a complexity $c=4$, the total number of elements is $4^{3}=64$. To determine the output data, the model uses an interpolation function. The minimized error depends on the methodology used. Thus, in Navarro-González and Villacampa $(2012,2013)$ the sum of the squared error (Equation 1 ) of the values obtained by the interpolation function at each point $\left(z_{j}\right)$ and the initial conditions $\left(P_{j}\right)$ is minimized. While in the methodology based on the Galerkin method (Navarro-González and Villacampa, 2016), the error ( $e(x)$-the difference between the solution and its approximation) is minimized by zeroing the integral defined in Equation 2, where NP is the number of variables in the model, $\vec{N}\left(P_{j}\right)$ is the interpolation function used to determine the value of the model at any point and $W_{j}(x)$ is the selected weight function (collocation method, sub-domain method, Least Square Method, Galerkin method, method of moments). In order to select the complexity, the generation and validation data of the model are used. Thus, the lower complexity that offers better results is selected, in order not to overfit the model.

Error $=\sum_{j=1}^{N P}\left(\vec{N}\left(P_{j}\right) \vec{u}-z_{j}\right)^{2}$ 
The criterion for selecting the optimal model was, first, the $R^{2}$ value. The coefficient of determination $\left(R^{2}\right)$ allows us to measure the goodness of fit and decide whether the linear adjustment performed is sufficient or should alternative models be sought. However, for nonlinear numerical models (as in our case), the value of $R^{2}$, is a guideline, since a model with a low value of $R^{2}$ can offer good results. Therefore, to determine the performance of the models and select the optimal model, the following errors were used: absolute error (Equation 3); mean magnitude of the relative error (Equation 4); and relative percentage error (Equation 5), which have been previously used by other authors (Aragonés et al., 2016b; Hashemi et al., 2010; Liu et al., 2012).

$e=\left|r_{i}-o_{i}\right|$

$\delta=\sqrt{\frac{\sum_{\mathrm{i}=1}^{\mathrm{n}}\left(\mathrm{r}_{\mathrm{i}}-o_{\mathrm{i}}\right)^{2}}{(\mathrm{n}-\mathrm{p}) \frac{1}{\mathrm{n}} \sum_{\mathrm{i}=1}^{\mathrm{n}}\left(\mathrm{r}_{i}\right)^{2}}}$

209

Where $r_{i}$ are the real measured data, $o_{i}$ are the data estimated by the model, $n$ is the number of data, and $p$ is the number of free parameters.

Numerical models were validated with the $10 \%$ of the studied beaches ( 30 beaches) using experimental data from subsequent years (2015-2016) to model adjustment data (2012-2015). Beaches were selected randomly, but taking into account that all the types of studied beaches (type of sediment, level of urbanization, etc.) were included.

\section{Results}

Results obtained from linear correlations between the analysed variables and $E$. coli concentrations are shown in Table 2. From the table it can be seen that the sun hours, rainfall and goat cattle have a greater direct influence on E. coli. However, correlation values were generally low, always lower than 0.35 . Furthermore, nine main components, which explain $81.6 \%$ of the variance, were obtained from the PCA (see supplementary material 2). Among these components, the first three explain more than $52 \%$ of the variance. The variables that are more related to the first component are representative of the livestock, and it is observed that the temperature of the water and UV have also significant weight. The second component are related to the Posidonia oceanica (stem height ($0.705)$ and plant density $(-0.791))$. And in the main variables of the third component are the hours of sun $(-0.814)$ and the purification rate $(0.877)$, which by their definition have no relation between them.

Table 2. Study of correlations ( $r$ ) between studied variables and E. coli.

\begin{tabular}{lclc}
\hline \multicolumn{1}{c}{ Variables } & Correlation $(\mathbf{r})$ & \multicolumn{1}{c}{ Variables } & Correlation (r) \\
\hline Sun hours & -0.349 & Distance to any type of discharge & -0.164 \\
Rainfall & 0.335 & Width of meadow & -0.162 \\
Goat cattle & 0.308 & Temperature & -0.148 \\
Depth final meadow & -0.271 & Density of beams & -0.139 \\
Depth medium meadow & -0.268 & Orientation & -0.134 \\
Presence of Posidonia oceanica & -0.267 & All discharges (rivers, gullies and waste) & 0.128 \\
\hline
\end{tabular}




\begin{tabular}{lclc}
\hline Others cattle & -0.224 & Sediment & -0.127 \\
Population density & 0.220 & Distance to residual discharges & -0.122 \\
Depth beginning of meadow & -0.207 & Purification rate & 0.088 \\
UV & 0.202 & Wave period & -0.060 \\
Heads of cattle (total number) & -0.194 & Level of urbanization & -0.059 \\
Ravines or rivers & 0.177 & Morphology & -0.056 \\
Salinity & 0.176 & Sheep cattle & -0.045 \\
Residual discharges & -0.175 & Distance to ravines or river & -0.029 \\
Wind & 0.175 & Population & 0.017 \\
Stem height & -0.172 & $\mathrm{H}_{\mathrm{s}, 12}$ & -0.004 \\
Pig cattle & -0.165 & & \\
\hline
\end{tabular}

Following the criteria stated in section 3.2 for the selection of variables, more than 20 mathematical models, using different combinations of the 33 studied variables, were generated to express the relationship between the variables and the concentration of $E$. coli in bathing waters. Among the models there were 6 that provided significant results and they are reproduced in Table 3.

Table 3. Variables used in each of the models.

\begin{tabular}{|c|c|c|c|c|c|}
\hline 6 Variables & 8 variables & 11 variables & 11 variables_2 & 12 variables & 13 variables \\
\hline Sun hours & Sun hours & Sun hours & Sun hours & Sun hours & Sun hours \\
\hline Rainfall & Rainfall & Rainfall & Rainfall & Rainfall & Rainfall \\
\hline Goat cattle & Goat cattle & Goat cattle & Goat cattle & Goat cattle & Goat cattle \\
\hline UV & UV & UV & UV & UV & UV \\
\hline $\begin{array}{c}\text { Population } \\
\text { density }\end{array}$ & $\begin{array}{l}\text { Population } \\
\text { density }\end{array}$ & $\begin{array}{c}\text { Population } \\
\text { density }\end{array}$ & $\begin{array}{c}\text { Population } \\
\text { density }\end{array}$ & $\begin{array}{c}\text { Population } \\
\text { density }\end{array}$ & $\begin{array}{c}\text { Population } \\
\text { density }\end{array}$ \\
\hline Presence of & Presence of & Presence of & Presence of & Presence of & Presence of \\
\hline $\begin{array}{c}\text { Posidonia } \\
\text { oceanica }\end{array}$ & $\begin{array}{c}\text { Posidonia } \\
\text { oceanica }\end{array}$ & $\begin{array}{c}\text { Posidonia } \\
\text { oceanica }\end{array}$ & $\begin{array}{c}\text { Posidonia } \\
\text { oceanica }\end{array}$ & $\begin{array}{c}\text { Posidonia } \\
\text { oceanica }\end{array}$ & $\begin{array}{c}\text { Posidonia } \\
\text { oceanica }\end{array}$ \\
\hline- & $\begin{array}{c}\text { Level of } \\
\text { urbanization }\end{array}$ & $\begin{array}{c}\text { Level of } \\
\text { urbanization }\end{array}$ & $\begin{array}{c}\text { Level of } \\
\text { urbanization }\end{array}$ & $\begin{array}{c}\text { Level of } \\
\text { urbanization }\end{array}$ & $\begin{array}{c}\text { Level of } \\
\text { urbanization }\end{array}$ \\
\hline- & Sediment & Sediment & Sediment & Sediment & Sediment \\
\hline- & - & Purification rate & Purification rate & Purification rate & Purification rate \\
\hline- & - & Salinity & Salinity & Salinity & Salinity \\
\hline- & - & $\begin{array}{l}\text { Distance to } \\
\text { ravines or rivers }\end{array}$ & $\begin{array}{l}\text { Distance to any } \\
\text { type of discharge }\end{array}$ & $\begin{array}{l}\text { Distance to any } \\
\text { type of discharge }\end{array}$ & $\begin{array}{l}\text { Distance to any } \\
\text { type of discharge }\end{array}$ \\
\hline- & - & - & - & $\mathrm{H}_{\mathrm{s}, 12}$ & $\mathrm{H}_{\mathrm{s}, 12}$ \\
\hline- & - & - & - & - & Period $(T)$ \\
\hline
\end{tabular}

Fig. 2 shows the $R^{2}$ values for each of the generated models, with significant results. The values of $R^{2}$ increase as the complexity of the model and the number of independent variables increase. However, for more than 11 variables, the value of $R^{2}$ decreases slightly (12 variables model, $R^{2}=$ $0.775 \pm 0.019$ ). Thus, for example, the model with six variables has an $R^{2}$ value of $0.458 \pm 0.037$, and for the 11 variables_2 model is $0.780 \pm 0.057$, but when the number of variables is increased to 13 , the $R^{2}$ decrease slightly $(0.752 \pm 0.035)$. 


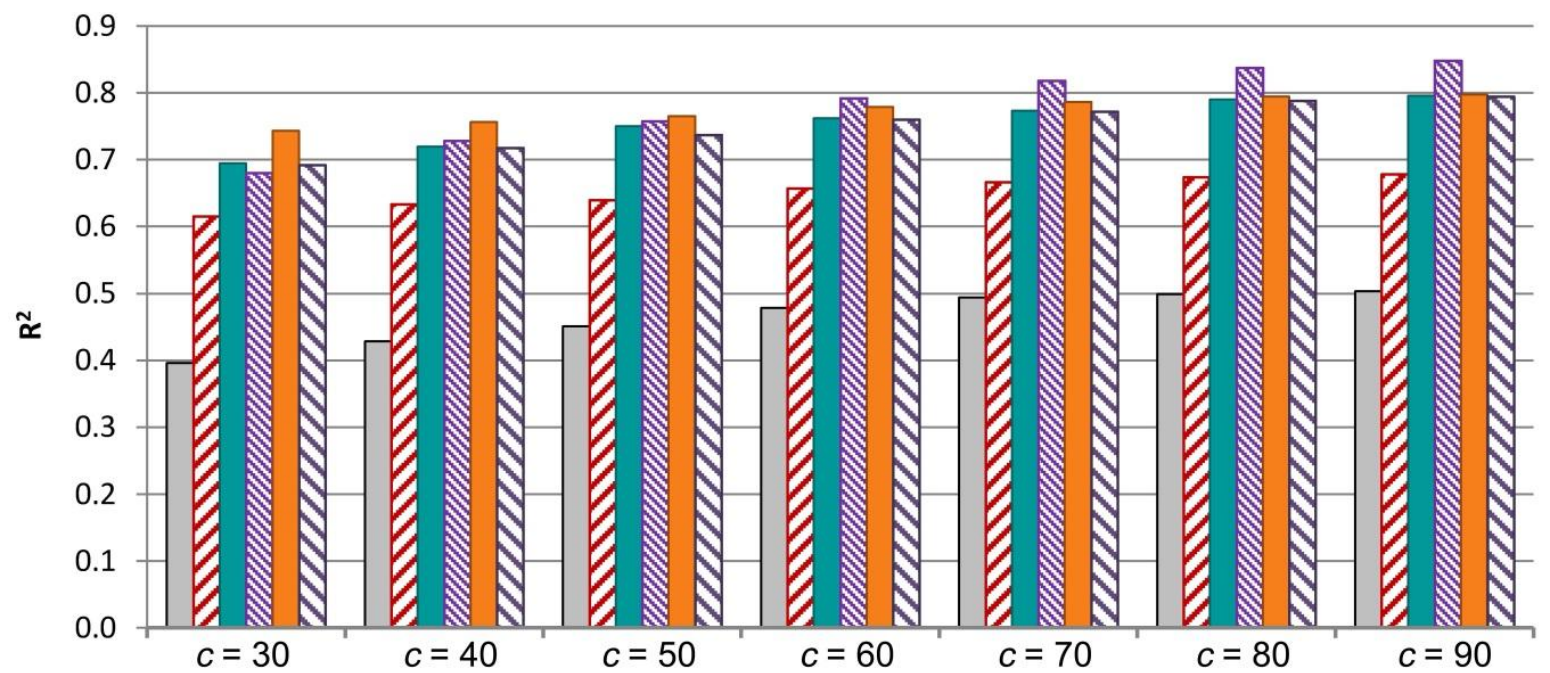

However, when the errors are analysed, a big difference is observed. Thus, Fig. 3 shows that the model of eight variables improves by $29.8 \%$ the absolute error of the six variables model. When adding two new variables (models with 11 variables) the mean absolute error decreased $(13.1 \pm 1.9$ CFU/100 ml for 11 variables and $12.8 \pm 2.7 \mathrm{CFU} / 100 \mathrm{ml} 11$ variables_2). If variables continued to be added (12 variables) the error decreased to $11.3 \pm 1.1 \mathrm{CFU} / 100 \mathrm{ml}$. However, when the variables were increased ( 13 variables) so did the error $13.5 \pm 1.9 \mathrm{CFU} / 100 \mathrm{ml}$. As observed, the error of the 13 variables model is similar to 11 variables model but with a greater standard deviation for each of the studied complexities ( 2.02 versus $1.35 \mathrm{CFU} / 100 \mathrm{ml}$ ).

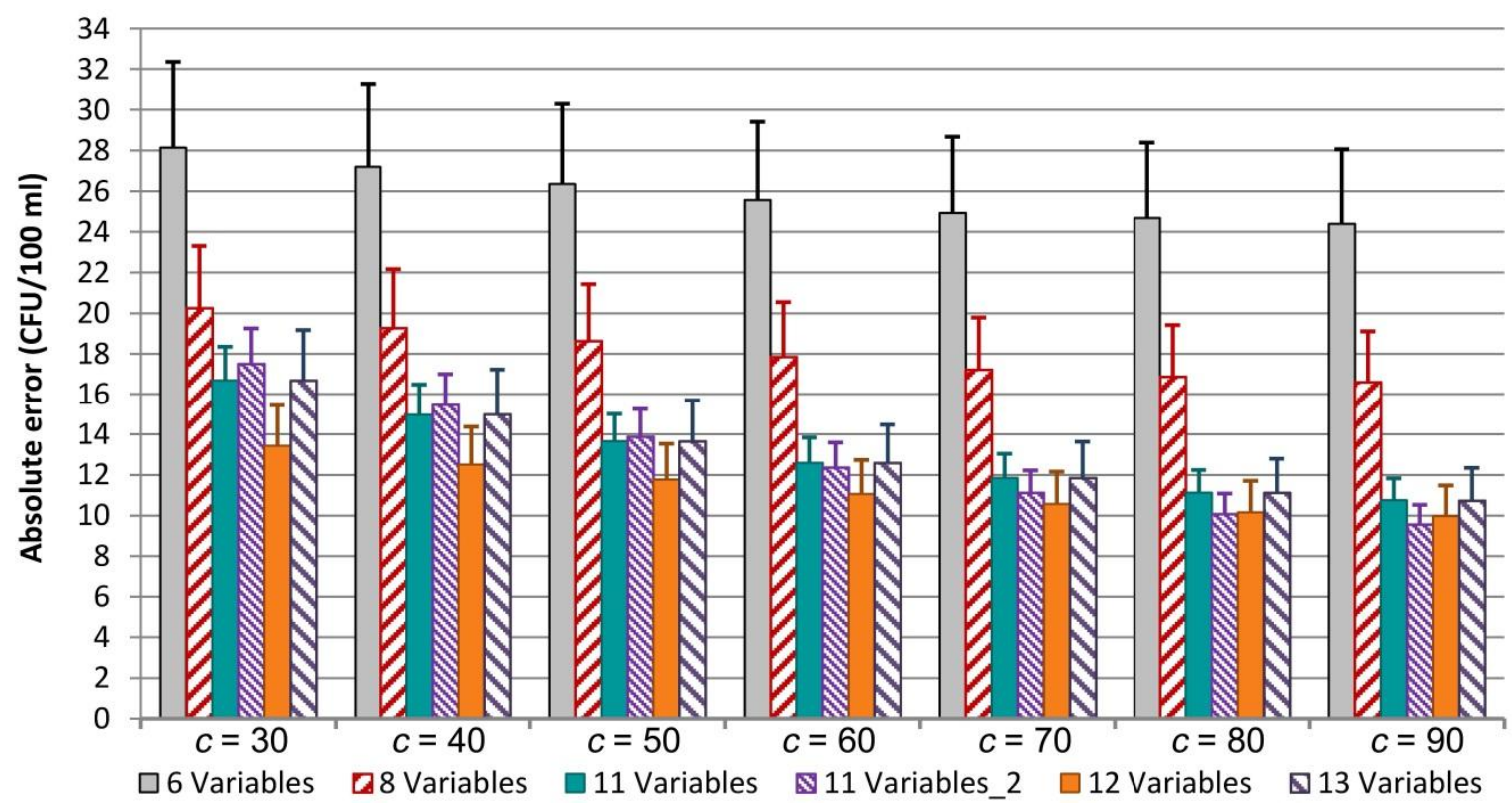

Fig. 3. Absolute error (CFU/100 ml) for each of the studied models.

Regarding the MAPE (Fig. 4a) and the relative percentage error (Fig. 4b) something similar to what happens with absolute error occurs. As the number of variables and the complexity of the model increases, errors decrease, reaching the values indicated in the 12 variables model and the complexity 90 of $27.1 \pm 4.1 \%$ and $0.370 \pm 0.055$ for MAPE and relative percentage error, respectively. However, when the number of variables increases to 13 variables, the mean error is very similar to 
the 11 variables model but the standard deviation increases. For example, for complexity 90 , the MAPE of 13 variables model is $38.3 \pm 5.7 \%$ and the relative percentage error is $0.372 \pm 0.056$.
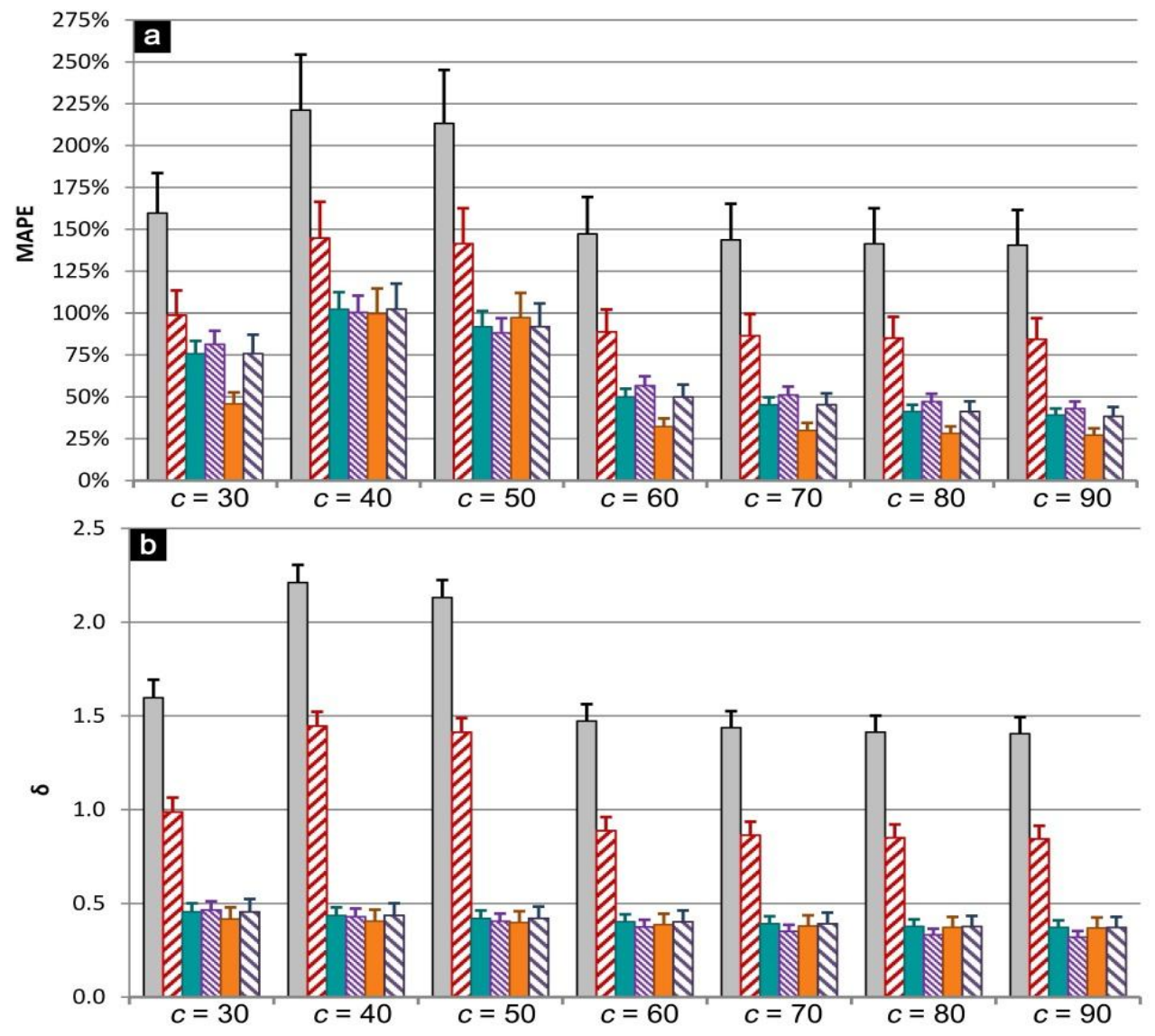

口6 Variables $\square 8$ Variables $\square 11$ Variables $\$ 11$ Variables_2 $\square 12$ Variables $\$ 13$ Variables

Fig. 4. a) MAPE and b) relative percentage error, for each of the studied models.

262

Once the model was chosen (12 variables), the results were validated. As can be seen, the errors committed during validation (Fig. 5) were very similar to those made during calibration. For the absolute error, errors increase by a mean of $9.2 \%$ ( $+1.04 \mathrm{CFU} / 100 \mathrm{ml})$, except for the model of complexity 80 where the increase is $17.4 \%$ (+1.9 CFU/100 ml). Something similar happens with MAPE, but with higher increase, reaching $22.1 \%(+11.4 \%)$ on average. Finally, the measured data were compared with the modelled data and the quality limits established by Directive 2006/7/EC (Fig. 6). The differences observed are small and the quality assigned to the modelled data is the same as that assigned to the measured data.

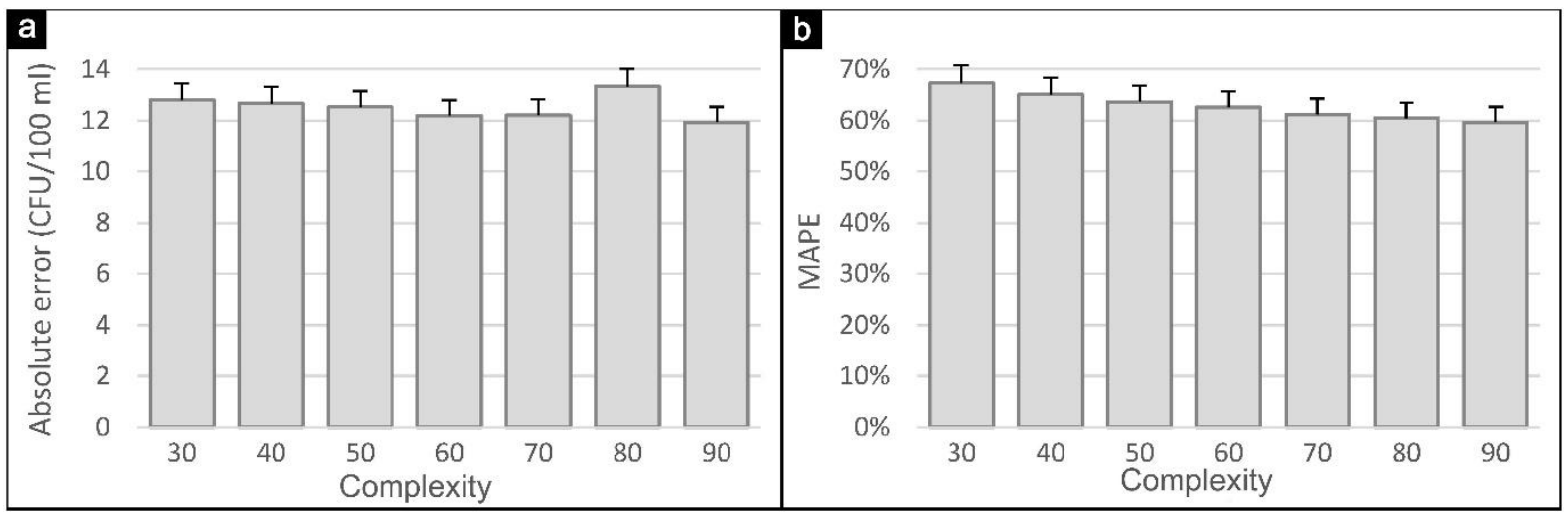

Fig. 5. a) Absolute error and b) MAPE, for validation data. 


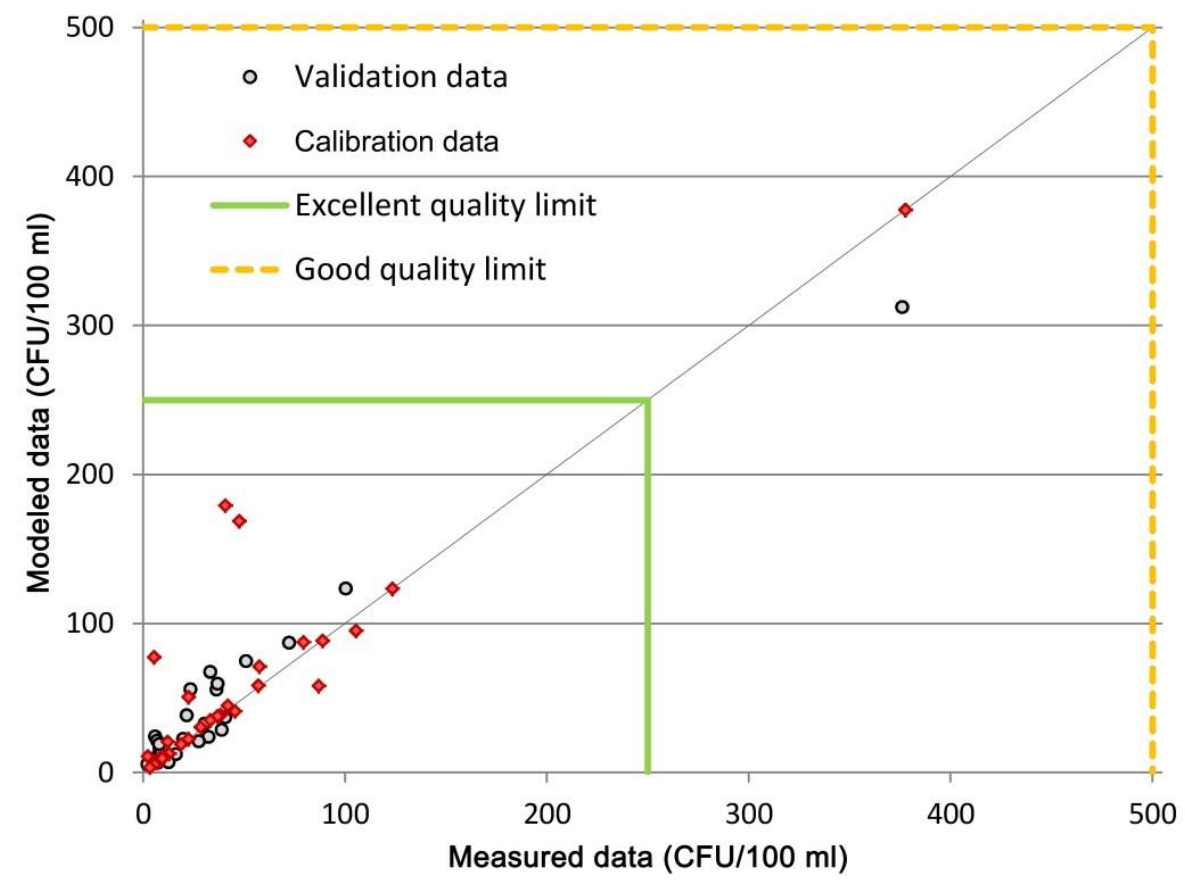

Fig. 6. Measured and modeled data during the model (12 variables and complexity 70 ) calibration and validation, for the 30 beaches used for validation.

\section{Discussion}

Several studies have shown that there is a relationship between gastrointestinal symptoms and the quality of recreational waters, which is determined by measuring the number of bacteria (Prüss, 1998). Therefore, given the popularity of the use of coastal waters for recreational purposes, quality minimums must be met (Sardá and Fluviá, 1999). In order to avoid endangering the health of users, regulators set limits on the maximum concentrations of faecal bacteria in the water. In Europe these values are described in Directive 2006/7/EC. To know the concentration of faecal bacteria during the bathing season, regulators carry out costly microbiological analyses once every 2 weeks. In this study, a model was generated to obtain the concentration of $E$. coli in coastal bathing waters, in order to reduce the number of microbiological analyses.

First, the bivariate correlations between the analysed variables and the concentration of $E$. coli were studied (Table 2). The variables with the highest direct correlation are: sun hours $(-0.349)$, precipitation (0.335) and goat cattle $(0.308)$, so these variables are in all models. To these three variables were added other variables following the criterion described in section 3.2. Thus, the first model that presented significant results was the 6 variables model (sun hours, rainfall, goat cattle, presence of Posidonia oceanica, population density and UV), with values of $R^{2}$ between $0.396-0.504$ (Fig. 2), and average absolute error of $25.9 \mathrm{CFU} / 100 \mathrm{ml}$. From the PCA, is extracted that there are no strong relationships between the explanatory variables that have been used later to generate the models. It is observed that there are no correlation between variables that a priori can be thought that are possibly correlated to each other, as can be the temperature, the hours of sun and the ultraviolet radiation. Although, it is true that there is a certain relationship between ultraviolet radiation and temperature, neither of the two variables has been used together in the generated models. 
The results of this model ( 6 variables) confirm the relationship, established by other authors, between these six variables and the concentration of $E$. coli. For example, according to Abdelzaher et al. (2010); Whitman et al. (2004); Zagarese et al. (1998) the concentration of E. coli decreases with UV, and increases with the low temperatures which is directly related to the hours of sunlight (Bathingwatercommittee, 2009; Bogosian et al., 1996; Brettar and Höfle, 1992; Sampson et al., 2006; Smith et al., 1994). Other authors, such as Rijal et al. (2009) indicate the importance of the volume of precipitation. Higher precipitation influences E. coli concentration in the following ways: i) allows an increase in bacteria dilution, which could reduce the concentrations (Cho et al., 2010); ii) modifies salinity conditions of water; iii) runoff waters clean the land surface and drag the pathogens toward the coast, increasing the bacterial concentration in coastal waters; and iv) Increases the flows of rivers, ravines, rainwater, which flow out to sea with all kinds of contaminants, such as animal defecations (Gibbs, 2001). This last point, could explain the high correlation obtained between the goat cattle and the $E$. coli, since in the studied area, goats usually freely graze on pastures (Meseguer and Espín, 2001), while the other livestock (bovine, porcine, etc.) are characterized by intensive, farms, and their excreta accumulate in the barn and are used as manure in agriculture (Ferrer et al., 2000). Meanwhile, Hammami et al. (2013) and Luzi et al. (2016) observed that Posidonia oceanica has an antibacterial function against $E$. coli bacteria.

Moreover, population density during the bathing season has a significant influence on bacterial concentration, due to the drastic increase in the number of users (Ariza et al., 2010). Also, urban development in the beach environment generally worsens the water quality of the beach. Ariza et al. (2008) observed that urban sandy beaches are the most affected by bacterial contamination since they are more accessible and accommodate more bathers. In addition, several recent studies indicate that bacterial indices may be associated with sewer leakage (generally ubiquitous in urban areas) due to aging infrastructure (Sercu et al., 2009). The type of sediment also influences the concentration of bacteria, because $E$. coli is able to reproduce in the sand if the necessary conditions of nutrients, predators and environmental conditions occur (Alm et al., 2006; Yamahara et al., 2007), where it can persist for longer and then be transferred to the sea. In addition, the smaller the sediment size, the greater the number of particles that can be suspended when the waves break, making it difficult to purify water by UV (Abdelzaher et al., 2010; Haugland et al., 2005; Salcedo et al., 2002). The degree of urbanization and the sediment type has a significant influence on bacterial concentration, as confirmed by the results of the 8 variables model, which decreases the absolute error by $30 \%$, although it is higher than $16 \mathrm{CFU} / 100 \mathrm{ml}$ (Fig. 3).

The models that showed improvement $-11,12$ and 13 variables models - included salinity which is inversely correlated to E. coli (Aragonés et al., 2016a; Mallin et al., 2000), the purification ratio and the distance to discharges. It was observed that the distance from the rivers or ravines to the beach is important (Fig. 3-5), since there is a great improvement in the results when this variable is added to the models (improvement of $28 \%$ against the 8 variables model). However, the distance to any type of discharge is more important, because to replace the variable "distance to rivers and ravines" by the variable "distance to any type of discharge" the improvement is $35 \%$. This is logical considering that the purification ratio of wastewaters is usually not $100 \%$, but they are treated to eliminate the highest possible percentage of pollution and then are discharged into the sea to continue the purification process (Yamahara et al., 2007). In addition, other studies have observed that areas located near agricultural or similar discharges present a higher concentration of faecal bacteria than those located near other kind of discharges (Palazón et al., 2017). This can be due to 
the trapping of fertilizers and contaminants of the irrigation waters, as well as to the lack of regulation and control in the discharge of these waters into the sea.

The incident wave $\left(\mathrm{H}_{\mathrm{s}, 12}\right)$ and its related period are intimately linked to the discharges and their distance to the beach, since currents may move the discharges onshore or offshore. It has also been observed that, generally, beaches whose coasts are parallel to the wave front have a higher concentration of bacteria (Palazón et al., 2017), perhaps because of the turbidity that is generated when the wave breaks. This explains the improvement that occurs in the modelling by including the wave height as input variable. Although the absolute error is similar to that of the 11 variables model (11.4 vs. $12.8 \mathrm{CFU} / 100 \mathrm{ml}$, Fig. 3), the MAPE is much lower (29.3\% vs. $43.8 \%$, Fig. 4a). However, including the period in the models does not improve the results, they are even slightly worse $(11.35$ vs. $13.09 \mathrm{CFU} / 100 \mathrm{ml}$, Fig. 3).

For validation, unlike conventional models that use a percentage of the set data to calibrate the model and the rest for validation, in this study, a set of data from the 2015-2016 bathing season was used whereas data from 2012-2015 was introduced into calibration model. The data used for validation come from 30 beaches, randomly selected, but taking into account that they include all the types and degrees of urbanization, sediment, etc. The errors during the validation are similar to the errors during calibration (Fig. 5), which means that the model is valid and not over-adjusted. If the model were over-adjusted, when different data are used for validation the results would be much worse than the results of the calibration.

Finally, the analysis of the models shows that there are two types of variables: i) variables directly related to humans or their activity (population density, livestock, level of urbanization and purification ratio); and ii) variables related to the environment (rainfall, UV, sunshine hours, Posidonia oceanica, sediment and salinity). Therefore, we can affirm that except for important modifications in the analysed variables, the concentrations of $E$. coli will remain more or less stable. In that case, the model can replace microbiological analysis, which could be performed only once during each bathing season (rather than every two weeks) in order to corroborate the model results. This study also shows that in order to further improve the results of the models, the effect of currents, tides, or sediment transport should be included in future studies.

\section{Conclusion}

Quality control and monitoring of bathing water based on measuring the concentration of faecal bacteria, such as $E$. coli, requires numerous microbiological analyses. The objective of this study to obtain a model that enables the measurement of $E$. coli in coastal bathing waters in order to reduce the microbiological analyses has been achieved. From the analysis of the results and the models that were generated, the following conclusions can be made:

- The relationship between the studied variables and the concentration of $E$. coli is not linear, which is confirmed by the study of correlations and the poor results of the linear models.

- The model with the best results is the 12 variables model and complexity 70, obtaining an mean absolute error of $10.6 \pm 1.5 \mathrm{CFU} / 100 \mathrm{ml}$ and a MAPE of $29.9 \pm 4.5 \%$

- The most important variables are: sun hours, rainfall, goat cattle, UV, presence of Posidonia oceanica, population density, level of urbanization, type of sediment, purification ratio, salinity, distance to the nearest discharge, and wave height perpendicular to the coast. 
The authors thank the Ministerio de Agricultura, Alimentación y Medio Ambiente, and Organismo Público Puertos del Estado, for the information they provided has enabled this study.

\section{REFERENCIAS}

Abdelzaher, A.M.; Wright, M.E.; Ortega, C.; Solo-Gabriele, H.M.; Miller, G.; Elmir, S.; Newman, X.; Shih, P.; Bonilla, J.A., and Bonilla, T.D., 2010. Presence of pathogens and indicator microbes at a non-point source subtropical recreational marine beach. Applied and Environmental Microbiology, 76(3), 724-732.

Ackerman, D. and Weisberg, S.B., 2003. Relationship between rainfall and beach bacterial concentrations on Santa Monica Bay beaches. Journal of Water and Health, 1(2), 85-89.

Aemet. 2016. Agencia Estatal de Meteorología [Online]. Ministerio de Agricultura, Alimentación y Medio Ambiente, Gobierno de España. Available: www.aemet.es/es/idi/clima/registros climaticos.

Alm, E.W.; Burke, J., and Hagan, E., 2006. Persistence and potential growth of the fecal indicator bacteria, Escherichia coli, in shoreline sand at Lake Huron. Journal of Great Lakes Research, 32(2), 401-405.

Aragonés, L.; López, I.; Palazón, A.; López-Úbeda, R., and García, C., 2016a. Evaluation of the quality of coastal bathing waters in Spain through fecal bacteria Escherichia coli and Enterococcus. Science of The Total Environment, 566-567, 288-297.

Aragonés, L.; Villacampa, Y.; Navarro-González, F.J., and López, I., 2016b. Numerical modelling of the equilibrium profile in Valencia (Spain). Ocean Engineering, 123, 164-173.

Ariza, E.; Jiménez, J.A., and Sardá, R., 2008. A critical assessment of beach management on the Catalan coast. Ocean \& Coastal Management, 51(2), 141-160.

Ariza, E.; Jimenez, J.A.; Sarda, R.; Villares, M.; Pinto, J.; Fraguell, R.; Roca, E.; Marti, C.; Valdemoro, H., and Ballester, R., 2010. Proposal for an integral quality index for urban and urbanized beaches. Environmental Management, 45(5), 998-1013.

Bathingwatercommittee, 2009. Bathing Water Profiles: Best Practice and Guidance. European Enviroment Agency. EC DG ENV 2009 URL: http://ec.europa.eu/environment/water/waterbathing/pdf/profiles dec 2009.pdf.

Beckinghausen, A.; Martinez, A.; Blersch, D., and Haznedaroglu, B.Z., 2014. Association of nuisance filamentous algae Cladophora spp. with E. coli and Salmonella in public beach waters: impacts of UV protection on bacterial survival. Environmental Science: Processes \& Impacts, 16(6), 1267-1274.

Bogosian, G.; Sammons, L.E.; Morris, P.; O'neil, J.P.; Heitkamp, M.A., and Weber, D.B., 1996. Death of the Escherichia coli K-12 strain W3110 in soil and water. Applied and Environmental Microbiology, 62(11), 4114-4120.

Brettar, I. and Höfle, M., 1992. Influence of ecosystematic factors on survival of Escherichia coli after large-scale release into lake water mesocosms. Applied and Environmental Microbiology, 58(7), 2201-2210.

Brooks, C.P.; Antonovics, J., and Keitt, T.H., 2008. Spatial and temporal heterogeneity explain disease dynamics in a spatially explicit network model. The American Naturalist, 172(2), 149-159.

Callahan, K.M.; Taylor, D.J., and Sobsey, M.D., 1995. Comparative survival of hepatitis A virus, poliovirus and indicator viruses in geographically diverse seawaters. Water Science and Technology, 31(5-6), 189-193.

Cho, K.H.; Cha, S.M.; Kang, J.-H.; Lee, S.W.; Park, Y.; Kim, J.-W., and Kim, J.H., 2010. Meteorological effects on the levels of fecal indicator bacteria in an urban stream: A modeling approach. Water Research, 44(7), 2189-2202. 
Ecolevante 2006. Estudio ecocartográfico del litoral de las provincias de Alicante y Valencia, Dirección General de Costas, Ministerio de Medio Ambiente, Spain, [Available online: http://www.mapama.gob.es/es/costas/temas/proteccioncosta/ecocartografias/ecocartografia-alicante.aspx].

Ecomag 2009. Estudio ecocartográfico de las provincias de Granada, Almería y Murcia., Dirección General de Costas, Ministerio de Medio Ambiente, Spain [Available online: http://www.mapama.gob.es/es/costas/temas/proteccioncosta/ecocartografias/ecocartografia-murcia.aspx].

Englebert, E.T.; Mcdermott, C., and Kleinheinz, G.T., 2008. Impact of the Alga Cladophora on the Survival of E. coli, Salmonella, and Shigella in Laboratory Microcosm. Journal of Great Lakes Research, 34(2), 377-382.

Faust, K. and Raes, J., 2012. Microbial interactions: from networks to models. Nat Rev Micro, 10(8), 538-550.

Ferrer, M.; Monge, E., and Orus, F., 2000. Quantification of nitrogen chemical forms of pig slurries by different analytic methods. Anaporc, 86-101.

Frikha, F.; Kammoun, M.; Hammami, N.; Mchirgui, R.; Belbahri, L.; Gargouri, Y.; Miled, N., and BenRebah, F., 2011. Chemical composition and some biological activities of marine algae collected in Tunisia Composición química y algunas actividades biológicas de algas marinas recolectadas en Túnez. Ciencias Marinas, 37(2), 113-124.

Gantzer, C.; Maul, A.; Audic, J., and Schwartzbrod, L., 1998. Detection of infectious enteroviruses, enterovirus genomes, somatic coliphages, and Bacteroides fragilis phages in treated wastewater. Applied and Environmental Microbiology, 64(11), 4307-4312.

Gibbs, M.T., 2001. Aspects of the structure and variability of the low-salinity-layer in Doubtful Sound, a New Zealand fiord. New Zealand Journal of Marine and Freshwater Research, 35(1), 59-72.

Grayson, R.; Kay, P., and Foulger, M., 2008. The use of GIS and multi-criteria evaluation (MCE) to identify agricultural land management practices which cause surface water pollution in drinking water supply catchments. Water Science and Technology, 58(9), 1797-1802.

Hammami, S.; Salem, A.B.; Ashour, M.L.; Cheriaa, J.; Graziano, G., and Mighri, Z., 2013. A novel methylated sesquiterpene from seagrass Posidonia oceanica (L.) Delile. Natural product research, 27(14), 1265-1270.

Hashemi, M.R.; Ghadampour, Z., and Neill, S.P., 2010. Using an artificial neural network to model seasonal changes in beach profiles. Ocean Engineering, 37(14-15), 1345-1356.

Haugland, R.A.; Siefring, S.C.; Wymer, L.J.; Brenner, K.P., and Dufour, A.P., 2005. Comparison of Enterococcus measurements in freshwater at two recreational beaches by quantitative polymerase chain reaction and membrane filter culture analysis. Water Research, 39(4), 559568.

Ihcantabria 2013. Análisis Matemático y Estadístico de Variables Medioambientales (AMEVA). In: CANTABRIA, U.D. (ed.). Cantabria, Spain. Available online: http://ihameva.ihcantabria.com/.

Ine. 2016. Instituto Nacional de Estadística [Online]. Available: www.ine.es/inebaseDYN/cp30321/cp inicio.htm.

Kelsey, H.; Porter, D.E.; Scott, G.; Neet, M., and White, D., 2004. Using geographic information systems and regression analysis to evaluate relationships between land use and fecal coliform bacterial pollution. Journal of Experimental Marine Biology and Ecology, 298(2), 197-209.

Knothe, G.J., 2012. The influence of urbanization on streams: The use of GIS spatial analysis to study land use influence on fish communities, water quality and physical habitats in Southeast Texas. The University of Houston Clear Lake, Master's thesis, p.

Liao, H.; Krometis, L.-a.H., and Kline, K., 2016. Coupling a continuous watershed-scale microbial fate and transport model with a stochastic dose-response model to estimate risk of illness in an urban watershed. Science of The Total Environment, 551-552, 668-675. 
Liu, H.; Tian, H.-Q., and Li, Y.-F., 2012. Comparison of two new ARIMA-ANN and ARIMA-Kalman hybrid methods for wind speed prediction. Applied Energy, 98, 415-424.

López, I.; Aragonés, L.; Villacampa, Y.; Compañ, P., and Satorre, R., 2015. Morphological classification of microtidal sand and gravel beaches. Ocean Engineering, 109, 309-319.

Luzi, F.; Fortunati, E.; Jiménez, A.; Puglia, D.; Chiralt, C., and Torre, L., 2016. PLA Nanocomposites Reinforced with Cellulose Nanocrystals from Posidonia oceanica and ZnO Nanoparticles for Packaging Application. Journal of Renewable Materials, In press, Available online http://www.ingentaconnect.com/content/scrivener/irm/pre-prints/content-irm-2016-0051.

Magrama. 2016a. Encuestas Ganaderas, análisis del número de animales por tipos [Online]. Ministerio de Agricultura, Alimentación y Medio Ambiente, Gobierno de España. Available: www.mapama.gob.es/es/estadistica/temas/estadisticas-agrarias/ganaderia/encuestasganaderas/2016].

Magrama. 2016b. Guía de playas [Online]. Ministerio de Agricultura, Alimentación y Medio Ambiente, Gobierno de España. Available: www.mapama.gob.es/es/costas/servicios/guiaplayas/2016].

Magrama. 2016c. Saneamiento y depuración [Online]. Ministerio de Agricultura, Alimentación y Medio Ambiente, Gobierno de España. Available: www.mapama.gob.es/es/cartografia-ysig/ide/descargas/agua/saneamiento-y-depuracion.aspx 2016].

Mallin, M.A.; Williams, K.E.; Esham, E.C., and Lowe, R.P., 2000. Effect of human development on bacteriological water quality in coastal watersheds. Ecological applications, 10(4), 10471056.

May, C.W.; Horner, R.R.; Karr, J.R.; Mar, B.W., and Welch, E.B., 1999. Effects of urbanization on small streams in the Puget Sound ecoregion. Watershed Protection Techniques, 2(4), 79.

Mclellan, S.L., 2004. Genetic diversity of Escherichia coli isolated from urban rivers and beach water. Applied and Environmental Microbiology, 70(8), 4658-4665.

Mcquaig, S.; Griffith, J., and Harwood, V.J., 2012. Association of fecal indicator bacteria with human viruses and microbial source tracking markers at coastal beaches impacted by nonpoint source pollution. Applied and Environmental Microbiology, 78(18), 6423-6432.

Meseguer, E.G. and Espín, J.M.G., 2001. La ganadería de la Región de Murcia en el periodo 19602000. Papeles de geografía, 34, 163-190.

Mill, A.; Schlacher, T., and Katouli, M., 2006. Tidal and longitudinal variation of faecal indicator bacteria in an estuarine creek in south-east Queensland, Australia. Marine Pollution Bulletin, 52(8), 881-891.

Navarro-González, F.J. and Villacampa, Y., 2012. A new methodology for complex systems using ndimensional finite elements. Advances in Engineering Software, 48, 52-57.

Navarro-González, F.J. and Villacampa, Y., 2013. Generation of representation models for complex systems using Lagrangian functions. Advances in Engineering Software, 64, 33-37.

Navarro-González, F.J. and Villacampa, Y., 2016. A finite element numerical algorithm for modelling and data fitting in complex systems. International Journal of Computational Methods and Experimental Measurements, 4(2), 100-113.

Nayade. 2016. Sistema de Información Nacional de Aguas de Baño [Online]. Madrid, Spain. Available: http://nayade.msc.es/Splayas/home.html.

Palazón, A.; Aragonés, L.; López, I.; López-Úbeda, R., and Saval, J.M., 2017. Determination of the most influential factors in the concentration of bacteria in coastal waters. International Journal of Environmental Impacts, In press.

Partyka, M.L.; Bond, R.F.; Chase, J.A., and Atwill, E.R., 2017. Monitoring bacterial indicators of water quality in a tidally influenced delta: A Sisyphean pursuit. Science of The Total Environment, 578, 346-356.

Prüss, A., 1998. Review of epidemiological studies on health effects from exposure to recreational water. International Journal of Epidemiology, 27(1), 1-9. 
Puertos Del Estado. 2016. Puertos del Estado [Online]. Madrid, Spain: Ministerio de Fomento.

Available:

http://www.puertos.es/en-

Rijal, G.; Petropoulou, C.; Tolson, J.K.; Deflaun, M.; Gerba, C.; Gore, R.; Glymph, T.; Granato, T.; O'connor, C.; Kollias, L., and Lanyon, R., 2009. Dry and wet weather microbial characterization of the Chicago area waterway system. Water Science and Technology, 60(7), 1847-1855.

Ríos, N.; Medina, G.; Jiménez, J.; Yánez, C.; García, M.Y.; Di Bernardo, M.L., and Gualtieri, M., 2009. Actividad antibacteriana y antifúngica de extractos de algas marinas venezolanas. Revista Peruana de Biología, 16, 97-100.

S-Plus2000 1999. Guide to statistics, Mathsoft, Inc.

Salcedo, I.; Andrades, J.A.; Quiroga, J.M., and Nebot, E., 2002. Desinfección de aguas residuales urbanas mediante radiación ultravioleta: Aplicación el la EDAR de Jerez de la Frontera. Tecnología del Agua, (227), 42-56.

Sampson, R.W.; Swiatnicki, S.A.; Osinga, V.L.; Supita, J.L.; Mcdermott, C.M., and Kleinheinz, G.T., 2006. Effects of temperature and sand on $E$. coli survival in a northern lake water microcosm. Journal of Water and Health, 4(3), 389-393.

Sardá, R.; Avila, C., and Mora, J., 2005. A methodological approach to be used in integrated coastal zone management processes: the case of the Catalan Coast (Catalonia, Spain). Estuarine, Coastal and Shelf Science, 62(3), 427-439.

Sardá, R. and Fluviá, M. 1999. Tourist Development in the Costa Brava (Girona, Spain): A Quantification of Pressures on the Coastal Environment. In: SALOMONS, W., TURNER, R.K., LACERDA, L.D.andRAMACHANDRAN, S. (eds.) Perspectives on Integrated Coastal Zone Management. Berlin, Heidelberg: Springer Berlin Heidelberg.

Sercu, B.; Werfhorst, L.C.V.D.; Murray, J., and Holden, P.A., 2009. Storm Drains are Sources of Human Fecal Pollution during Dry Weather in Three Urban Southern California Watersheds. Environmental Science \& Technology, 43(2), 293-298.

Smith, P.; Hiney, M.P., and Samuelsen, O.B., 1994. Bacterial resistance to antimicrobial agents used in fish farming: A critical evaluation of method and meaning. Annual Review of Fish Diseases, 4, 273-313.

Spss12.0. 2003. Guide to statistics, Mathsoft, Inc.

Stewart, J.R.; Gast, R.J.; Fujioka, R.S.; Solo-Gabriele, H.M.; Meschke, J.S.; Amaral-Zettler, L.A.; Del Castillo, E.; Polz, M.F.; Collier, T.K., and Strom, M.S., 2008. The coastal environment and human health: microbial indicators, pathogens, sentinels and reservoirs. Environmental Health, 7(2), 1-14.

Vanden Heuvel, A.; Mcdermott, C.; Pillsbury, R.; Sandrin, T.; Kinzelman, J.; Ferguson, J.; Sadowsky, M.; Byappanahalli, M.; Whitman, R., and Kleinheinz, G.T., 2010. The Green Alga, Cladophora, Promotes Escherichia coli Growth and Contamination of Recreational Waters in Lake Michigan All rights reserved. No part of this periodical may be reproduced or transmitted in any form or by any means, electronic or mechanical, including photocopying, recording, or any information storage and retrieval system, without permission in writing from the publisher. Journal of Environmental Quality, 39(1), 333-344.

W.H.O. 2003. Guidelines for safe recreational water environments: Coastal and fresh waters, World Health Organization.

Whitman, R.L.; Nevers, M.B.; Korinek, G.C., and Byappanahalli, M.N., 2004. Solar and temporal effects on Escherichia coli concentration at a Lake Michigan swimming beach. Applied and Environmental Microbiology, 70(7), 4276-4285.

Winter, J. and Duthie, H., 1998. Effects of urbanization on water quality, periphyton and invertebrate communities in a southern Ontario stream. Canadian Water Resources Journal, 23(3), 245257. 
Yamahara, K.M.; Layton, B.A.; Santoro, A.E., and Boehm, A.B., 2007. Beach Sands along the California Coast Are Diffuse Sources of Fecal Bacteria to Coastal Waters. Environmental Science \& Technology, 41(13), 4515-4521.

Zagarese, H.E.; Cravero, W.; Gonzalez, P., and Pedrozo, F., 1998. Copepod mortality induced by fluctuating levels of natural ultraviolet radiation simulating vertical water mixing. Limnology and oceanography, 43(1), 169-174.

Zienkiewicz, O.C.; Taylor, R.L., and Taylor, R.L. 1977. The finite element method, McGraw-hill London. 